\title{
Water Management of River Beaches-A Portuguese Case Study
}

\author{
Maria Oliveira ${ }^{1}$, Margarida Antunes ${ }^{2, *}$ (1) and Ana Carvalho ${ }^{2}$ \\ 1 ICT Competency Center, University of Minho, Campus de Gualtar, 4710-057 Braga, Portugal; \\ maryy.oliveira15@hotmail.com \\ 2 CIM CÁVADO, Rua do Carmo, 29, 4700-309 Braga, Portugal; anacarvalho@cimcavado.pt \\ * Correspondence: imantunes@dct.uminho.pt
}

Citation: Oliveira, M.; Antunes, M.; Carvalho, A. Water Management of River Beaches-A Portuguese Case Study. Geosciences 2021, 11, 152. https://doi.org/10.3390/ geosciences11040152

\section{Academic Editors:}

Jesus Martinez-Frias and Marcos D. Mateus

Received: 26 January 2021

Accepted: 23 March 2021

Published: 27 March 2021

Publisher's Note: MDPI stays neutral with regard to jurisdictional claims in published maps and institutional affiliations.

Copyright: (c) 2021 by the authors. Licensee MDPI, Basel, Switzerland. This article is an open access article distributed under the terms and conditions of the Creative Commons Attribution (CC BY) license (https:/ / creativecommons.org/licenses/by/ $4.0 /)$.

\begin{abstract}
The quality of water is crucial for the qualification of river beaches. The Cávado River watershed (Northern Portugal) contains five river beaches with a regular and specific mandatory monitorization. The main subject of this research is the evaluation of spatial and temporal water microbiological and physicochemical parameters to assess the water quality improvement and consequently watershed management. The results of monitoring surface water, considering microbiological parameters from the five river beaches (2015/19), and physicochemical parameters from three water points along the Cávado River (2018/19) were considered. The river beaches located upstream of the town of Braga has an "excellent" and "good" quality, while the river beach located downstream shows a lower water quality. The physicochemical water results indicated that there is a progressive degradation of water quality from upstream to downstream of the river, which is associated with the influence of domestic and industrial activities. To improve water quality, continuous monitoring will be necessary, with the implementation of adequate awareness-raising programs and strategic water quality management by the population and local agents.
\end{abstract}

Keywords: Cávado River; hydrochemistry; inland beaches; Northern Portugal

\section{Introduction}

Tourism development is extremely important for the economy of local and regional municipalities. Especially in the coastal areas and river environments, tourism is highly dependent on the bathing water quality (BWQ) and the management of bathing waters in the European Union (EU) that is currently legislated under the EU Bathing Water Directive (BWD) [1].

Portugal is especially recognized by recreational tourism, particularly bathing tourism [2]. In the 1990, different investments were made, including the implementation of wastewater treatment plants and domestic infrastructures, resulting in an improvement of watercourses quality [2,3]. Inland river beaches are an opportunity for bathing tourism $[3,4]$.

Bathing waters are surface waters, whether inland, coastal, or transitional, where many people are expected to bathe and where bathing has not been permanently prohibited or advised against [5]. The management of water quality from river beaches is a crucial factor for public health, environmental quality, and tourism development $[2,3,5]$.

The evaluation of water quality of recreational beaches is currently based on the abundance of Faecal Indicator Bacteria (FIB) [6]. Elevated levels of FIB indicate possible faecal contamination of the water [7]. Escherichia coli and intestinal Enterococci are used to evaluate the level of faecal contamination in surface waters [6].

Rivers are widely receiving waters for wastewater treatment plant effluents, the direct inflow of untreated wastewater, and diffuse pollution, and, consequently, the water is severely impaired and contaminated [8-12]. Intensive land use, agriculture and livestock, industrial activities, and urbanization are also sources of contamination and become a serious problem for the quality of bathing water located downstream [8,9,13-16]. Extreme 
rainfall events increase the level of faecal contamination, which, consequently, affects the quality of bathing water $[7,15,17]$. Finding point and diffuse pollution sources of beaches and the measure of water quality is extremely important for ensuring that recreational beaches stay healthy and to prevent microbial contamination of these beaches $[18,19]$.

The qualification of river beaches is defined by the Portuguese Environment Agency concerning reference values of physicochemical and microbiological parameters [5]. The bathing water is classified as "excellent", "good", "acceptable" and "poor", according to the percentile value (95th for excellent and good, and 90th for acceptable and poor) for Escherichia coli and intestinal Enterococci obtained on the water in the last three bathing annual seasons. According to the percentile values for microbiological parameters, the water quality could be classified as: poor (Escherichia coli $>900 \mathrm{ufc} / 100 \mathrm{~mL}$, intestinal enterococci $>330 \mathrm{ufc} / 100 \mathrm{~mL}$ ); acceptable (Escherichia coli $\leq 900 \mathrm{ufc} / 100 \mathrm{~mL}$, intestinal enterococci $\leq 330$ ); good (Escherichia coli $\leq 1000 \mathrm{ufc} / 100 \mathrm{~mL}$, intestinal enterococci $\leq 400 \mathrm{ufc} / 100 \mathrm{~mL}$ ); and excellent (Escherichia coli $\leq 500 \mathrm{ufc} / 100 \mathrm{~mL}$, intestinal enterococci $\leq 200 \mathrm{ufc} / 100 \mathrm{~mL}$ ) [5]. During the bathing season, microbiological parameters must be monitored according to the parametric values of Portuguese legislation for Bathing Water (Escherichia coli $=1800$ ufc $/ 100 \mathrm{~mL}$, intestinal Enterococci $=660 \mathrm{ufc} / 100 \mathrm{~mL}$ ) [20,21].

The Bathing Water Quality (BWQ) requires a regular river water assessment before the beginning of the Portuguese bathing period (Spring season). The classification and qualification of the batching river water are supported by water monitorization in previous years. The Portuguese Intermunicipal Community of Cávado (CIM Cávado) promotes regular temporal and spatial campaigns to monitor surface water quality from Cávado River concerning the river beaches qualification [22].

The main subject of this research is the spatial and temporal water quality assessment from the river beaches included in the Cávado River watershed. There is no significant research available on the water quality from the watershed. This research is novel and will be crucial in allowing and recognizing possible contaminant sources and consequent definition of prevention and monitoring procedures.

\section{Materials and Methods}

\subsection{Cávado River Watershed}

The Cávado River watershed is located in the north of Portugal (Figure 1) with an area of $1699 \mathrm{~km}^{2}$ and a maximum length of $129 \mathrm{~km}$, mainly orientated NE-SW, and flowing into the Atlantic Ocean. The Cávado River has two important affluents: Homem River and Rabagão River [23]. The watershed area covers 14 local municipalities, which six of them are included on the Intermunicipal Community of Cávado. 
(a)

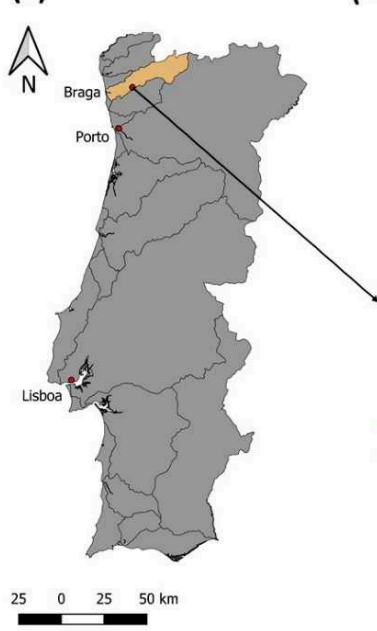

(b)

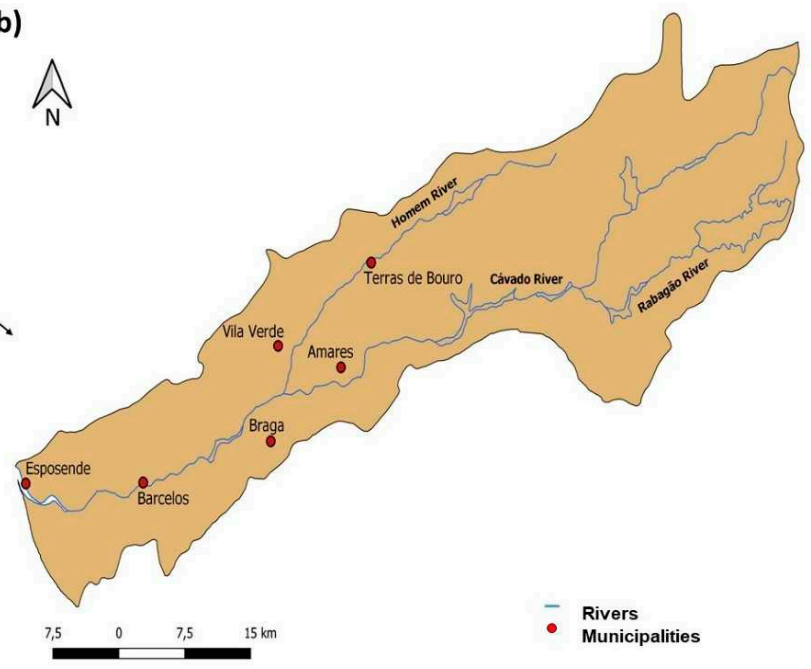

Figure 1. (a) Geographical setting of the Cávado River watershed. (b) Cávado River watershed with principal affluents and municipalities.

The Cávado River watershed registered total annual precipitation of 900-4200 mm/year with an average of $1998 \mathrm{~mm}$ /year and a hypsometry of 0-1600 $\mathrm{m}$ [23], with a decrease from upstream to downstream values in the river course (Figure 2a).

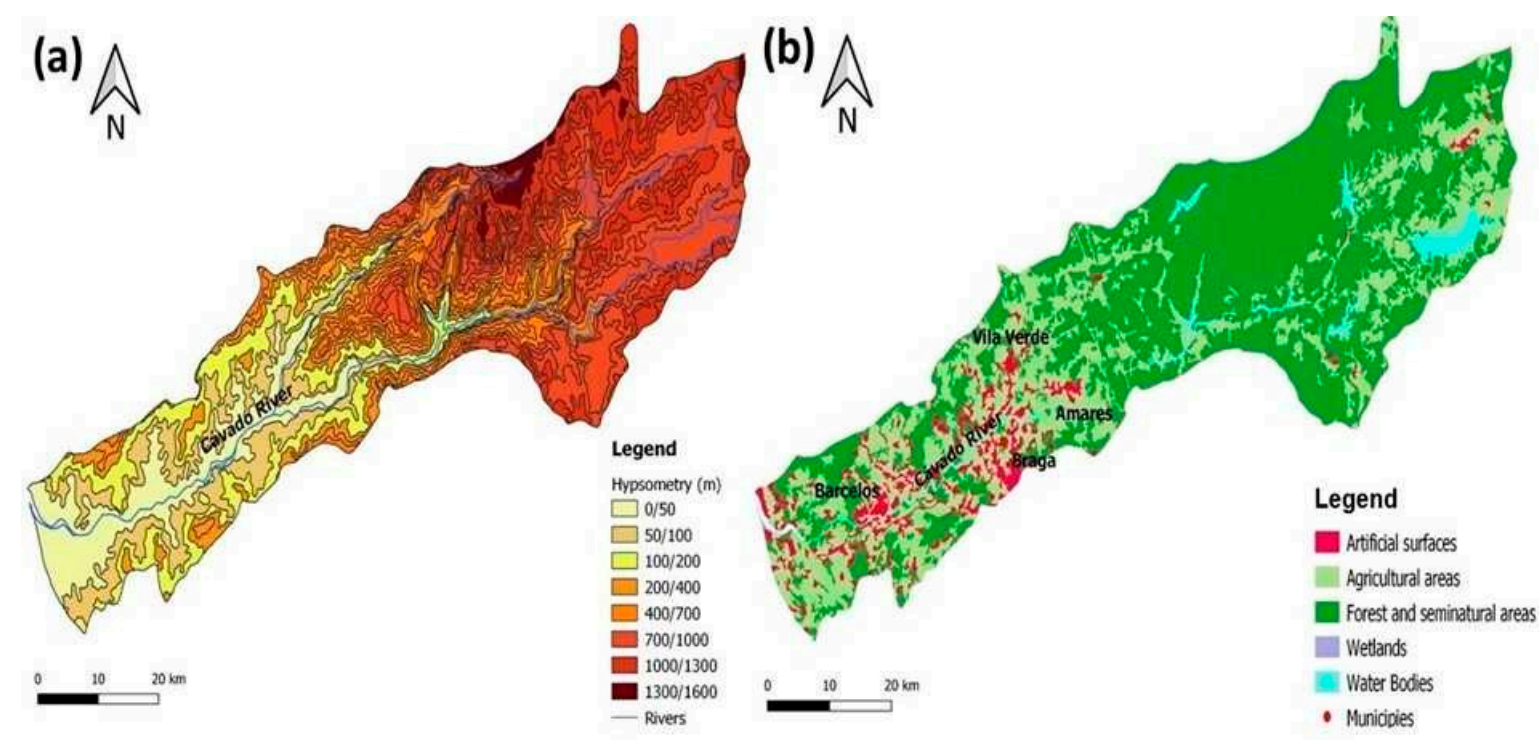

Figure 2. Cávado River watershed: (a) hypsomety and (b) land use (adapted from Reference [20]).

The soil occupation is represented by $67 \%$ forest and seminatural areas, $26 \%$ agriculture, urbanization $5 \%$ and $1 \%$ water bodies (Figure 2b) [24]. Agricultural and urban areas, including industry, occur distributed on the banks of the Cávado River. The upstream area of the Cávado River watershed has lower population density and industrial activity, with different agricultural areas. In the central area of the watershed, the population density and industrial activity is higher than in the previous one. However, agricultural activity is predominant. The downstream area has high levels of urban and industrial density [25].

The Cávado River watershed registered total annual precipitation of 900-4200 mm/year, with an average of $1998 \mathrm{~mm} /$ year, and a hypsometry of 0-1600 m [23], with a decrease from upstream to downstream the river course (Figure 2a).

The soil occupation is represented by $67 \%$ forest and seminatural areas, $26 \%$ agriculture, $5 \%$ urbanization, and $1 \%$ of water bodies (Figure 2b) [24]. Agricultural and urban 
areas, including industry, are distributed on the banks of the Cávado River. The upstream area of the Cávado River watershed has lower population density and industrial activity with different agricultural areas. In the central area of the watershed, the population density and industrial activity is higher than in the previous one. However, agricultural activity is predominant. The downstream area has high levels of urban and industrial density [25].

The occurrence of industry like the manufacture of metallic and non-metallic products, the manufacturing of machines and equipment, and the textile industry is higher in Braga and Barcelos's municipalities [25]. There are two industrial parks in Braga, nearly the Cávado River, and Wastewater Treatment Plants (WWTP) in Vila Verde (Cávado-Homem Wastewater Treatment Plant) and Braga (Frossos Wastewater Treatment Plant). The WWTP of Amares has been worked in a lagoon system, considered to be an environmental concern due to the incapacity of the regional requirements and associated discharges to Cávado River. This WWTP was deactivated at the end of 2015, which influenced the water quality of the Cávado River [23].

The highest populated municipalities, Braga (182,299 inhabitants) and Barcelos (116,359 inhabitants), are located further downstream and near the banks of the Cávado River due to the urbanization and industry, which promote a concentration of anthropogenic pressure [26].

In the Cávado River watershed, there are five qualified river beaches, namely: Alqueirão (Terras de Bouro Municipality), Adaúfe, Cavadinho, Navarra (Braga Municipality), and Prado Faial (Vila Verde Municipality) (Figure 3).

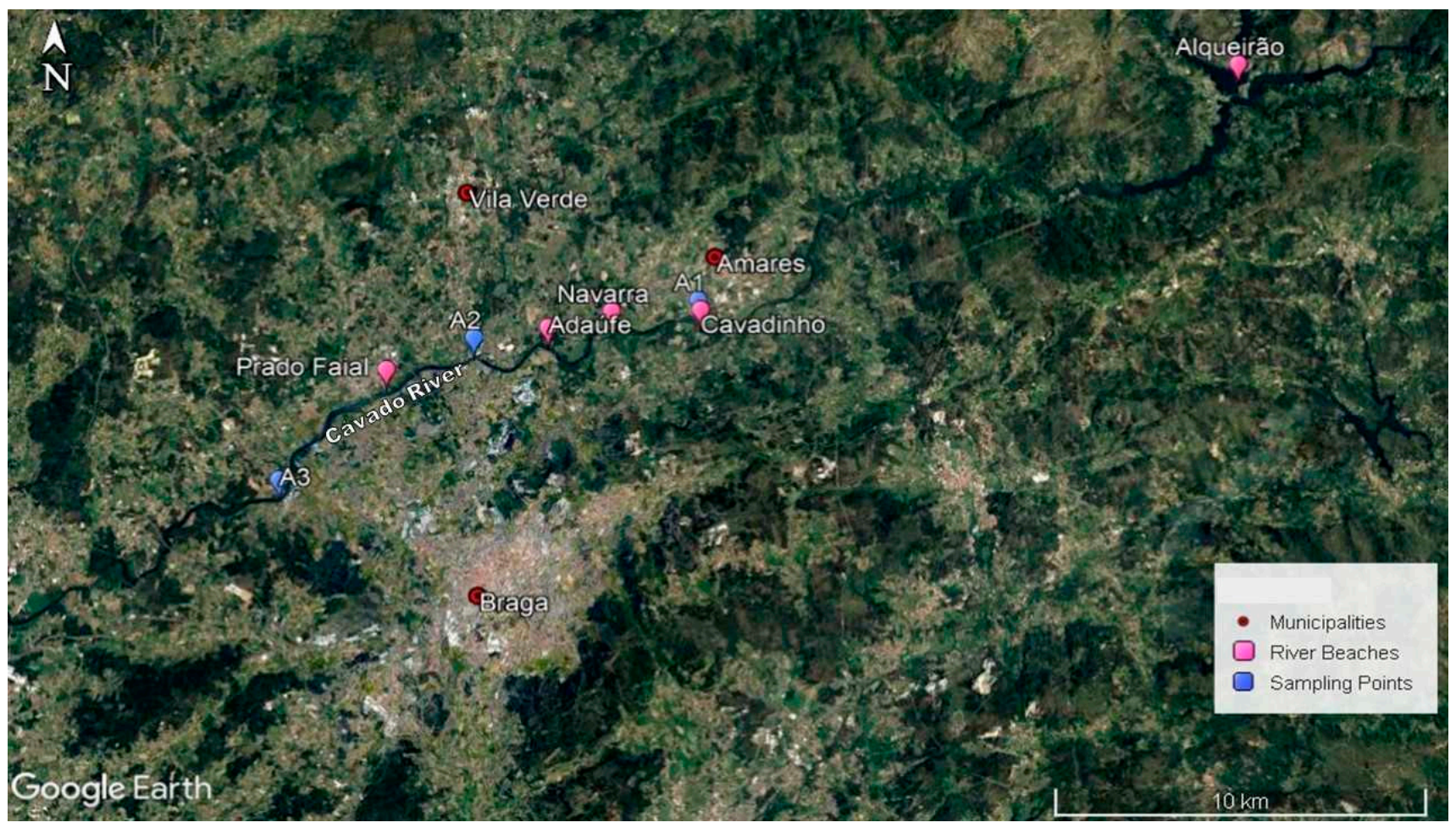

Figure 3. Location of the river beaches of: Alqueirão, Cavadinho, Navarra, Adaúfe, and Prado Faial, and water sampling points (A1-A3) in Cávado River (Google Earth).

\subsection{Water Characterization}

The microbiological parameters - Escherichia coli and intestinal Enterococci - obtained in the four months (June, July, August, and September), between 2015-2019 [27], were used to assess water quality on the five river beaches. A total of 298 values of microbiological parameters were collected from the site of the National Water Resources Information 
System [27]. For the statistics analysed, the maximum values obtained in each beach per month and year were considered ( $\mathrm{n}=20$ per beach).

Three sampling points from Cávado River, located between the river beaches, were selected, and analysed twice in the hydrological year. The two sampling campaigns were collected in November $2018(\mathrm{n}=3)$, corresponding to the rainy season, and April $2019(\mathrm{n}=3)$, corresponding to the dry season (Figure 3). Temperature, $\mathrm{pH}$, Electrical Conductivity (EC), total dissolved solids (TDS), and Eh were measured in situ using two multiparameter portable meters (HANNA Instruments Model HI 98129 and HI 98120). The six water samples were collected and stored in polyethylene bottles, which were correctly conditioned and transported to the laboratories. In the laboratory, the water samples were preserved to a temperature of $4{ }^{\circ} \mathrm{C}$ and filtered with a $0.45 \mu \mathrm{m}$ Millipore filter. Fluoride, chloride, nitrite, bromide, nitrate, phosphate, and sulphate results on water samples were analyzed by ion chromatography with an ionic chromatography Metrohm 761 Compact IC, and alkalinity by automatic titration Orion-Model 950 with $0.01 \mathrm{M}$ $\mathrm{HCl}$ [28], in the University of Minho (Braga, Portugal). Cadmium, Cu, Cr, Fe, Mn, Zn, P, and $\mathrm{K}$ results on water samples were determined by Atomic Absorption Spectrophotometry (AAS), As, Ba, and Li by ICP-MS, turbidity by turbidimetry, $\mathrm{Mg}$, $\mathrm{Ca}$, and bicarbonates by volumetry, and $\mathrm{NH}_{4}{ }^{+}$and $\mathrm{Al}$ by Molecular Absorption Spectrophotometry (MAS). All these elements and parameters were obtained in a certified laboratory-Microchem Laboratory (Matosinhos, Portugal).

Microbiological results from the water river beaches were compared with Portuguese legislation for Bathing Water parametric values (Escherichia coli $=1800 \mathrm{ufc} / 100 \mathrm{~mL}$; intestinal Enterococci $=660 \mathrm{ufc} / 100 \mathrm{~mL}$ ) $[20,21]$ while, for water chemical composition was used and the water quality parametric values from Portuguese legislation were used $[29,30]$.

\section{Results}

The maximum values for microbiological parameters of water river beaches from the Cávado river watershed were presented in Figure 4. The water from Alqueirão river beach did not show a significant temporal variation, between 2015 to 2019, relatively to Escherichia coli (Figure 4a) and intestinal Enterococci microbiological parameters ( $15 \mathrm{ufc} / 100 \mathrm{~mL}-110 \mathrm{ufc} / 100 \mathrm{~mL}$, Figure 4b). There is a decrease in Escherichia coli values from the water from Navarra river beach during 2019 (Figure 4e), while the maximum value of intestinal Enterococci is low, except in June 2017 (maximum value: $400 \mathrm{ufc} / 100 \mathrm{~mL}$, Figure $4 \mathrm{f}$ ), but without a significant variation.

The water from Adaúfe and Cavadinho river beaches present the lowest values of Escherichia coli and intestinal Enterococci. However, there is an increase in the intestinal Enterococci maximum values in Adaúfe river beach water in June 2016 ( $890 \mathrm{ufc} / \mathrm{mL})$, July (1300 ufc/100 mL) and august 2017 (1400 ufc/100 mL) (Figure 4h). The Escherichia coli maximum values occured during July 2017 (4005 ufc/100 mL) (Figure $4 \mathrm{~g}$ ). The water river beach from Cavadinho shows a maximum value of $820 \mathrm{ufc} / 100 \mathrm{~mL}$ for intestinal Enterococci in July 2018 (Figure 4d), while Escherichia coli maximum values range from $15 \mathrm{ufc} / \mathrm{mL}$ to $465 \mathrm{ufc} / \mathrm{mL}$, during the last five years (Figure $4 \mathrm{c}$ ).

The water from Prado Faial contains the highest Escherichia coli maximum values with a decrease between 2018 and 2019. However, in August 2019, a significant increase in the Escherichia coli parameter occurred (1884 ufc/100 mL) (Figure 4i). Prado Faial presents the lowest values of intestinal Enterococci, ranging between $15 \mathrm{ufc} / 100 \mathrm{~mL}$ and $77 \mathrm{ufc} / \mathrm{mL}$ (Figure 4j).

The water chemical contents of Cávado River sampling points are presented in Table 1, while seasonal variations of water $\mathrm{pH}$, temperature, electrical conductivity, total dissolved solids, $\mathrm{Ca}, \mathrm{Mg}, \mathrm{NO}_{3}{ }^{-}, \mathrm{Cl}^{-}, \mathrm{SO}_{4}{ }^{2-}$ contents, and turbidity values are represented in Figures 5 and 6 .

Table 1. Results of the chemical analysis on water samples from Cávado River.

\begin{tabular}{|c|c|c|c|c|c|c|c|}
\hline Parameters & $\begin{array}{c}\text { A1 } \\
\text { November } \\
2018\end{array}$ & $\stackrel{\text { A1 }}{\text { April } 2019}$ & $\begin{array}{c}\mathrm{A} 2 \\
\text { November } \\
2018\end{array}$ & $\begin{array}{c}\text { A2 } \\
\text { April } 2019\end{array}$ & $\begin{array}{c}\text { A3 } \\
\text { November } \\
2018\end{array}$ & $\begin{array}{c}\text { A3 } \\
\text { April } 2019\end{array}$ & $\begin{array}{c}\text { Parametric } \\
\text { Value }[29,30]\end{array}$ \\
\hline $\mathrm{Al}(\mu \mathrm{g} / \mathrm{L})$ & $<200$ & 55 & $<200$ & 83 & $<200$ & 103 & 200 \\
\hline Alkalinity $^{1}(\mathrm{mg} / \mathrm{L})$ & 4.52 & 3.93 & 4.75 & 33.39 & 8.68 & 16.92 & - \\
\hline $\begin{array}{l}\text { Bicarbonates } \\
(\mathrm{mg} / \mathrm{L})\end{array}$ & 7.32 & 6.59 & 8.05 & 6.83 & 23.7 & 21.0 & - \\
\hline
\end{tabular}




$$
=\text { June }=\text { July }=\text { August }=\text { September }-. \cdot \text { Parametric Value }
$$

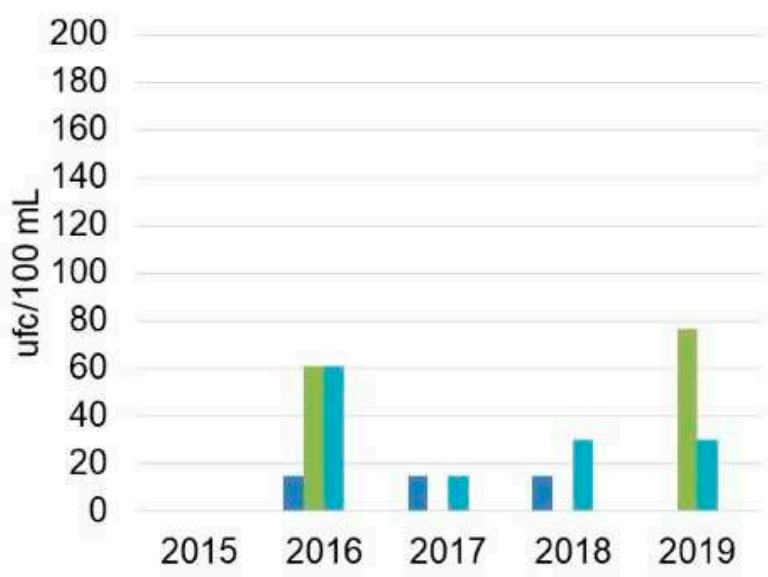

(a) Alqueirão-Escherichia coli

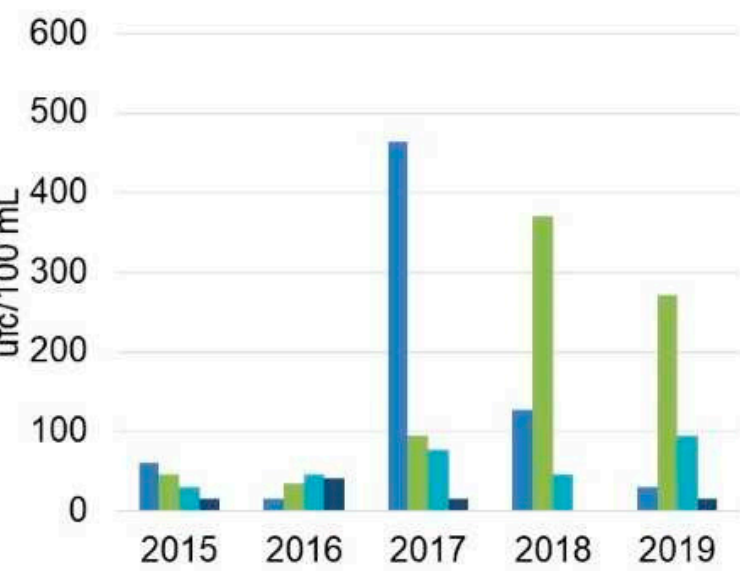

(c) Cavadinho-Escherichia coli

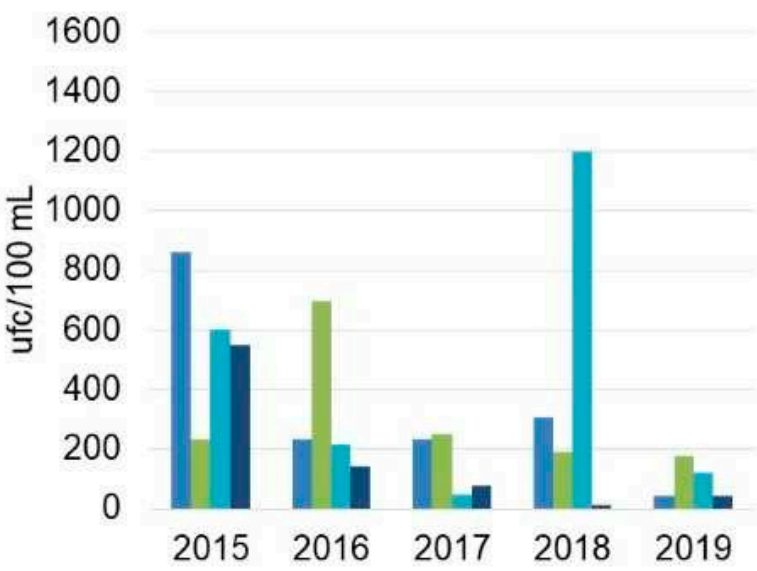

(e) Navarra - Escherichia coli

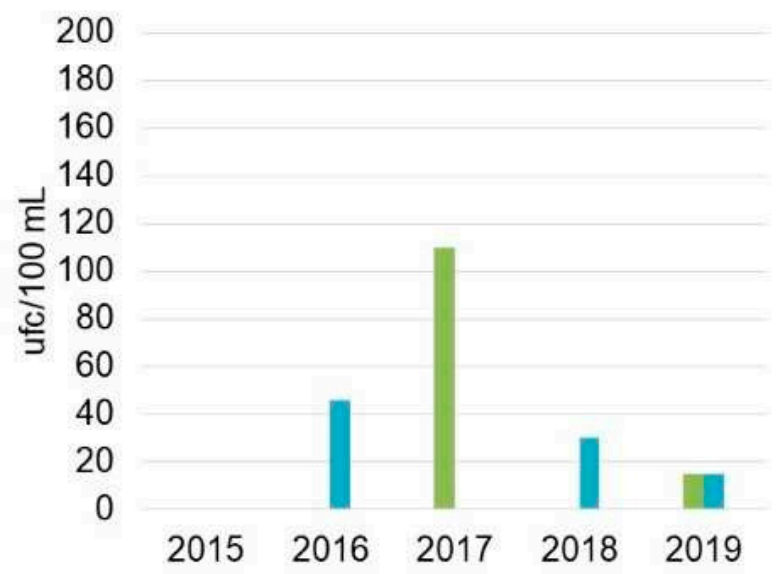

(b) Alqueirão - intestinal Enterococci

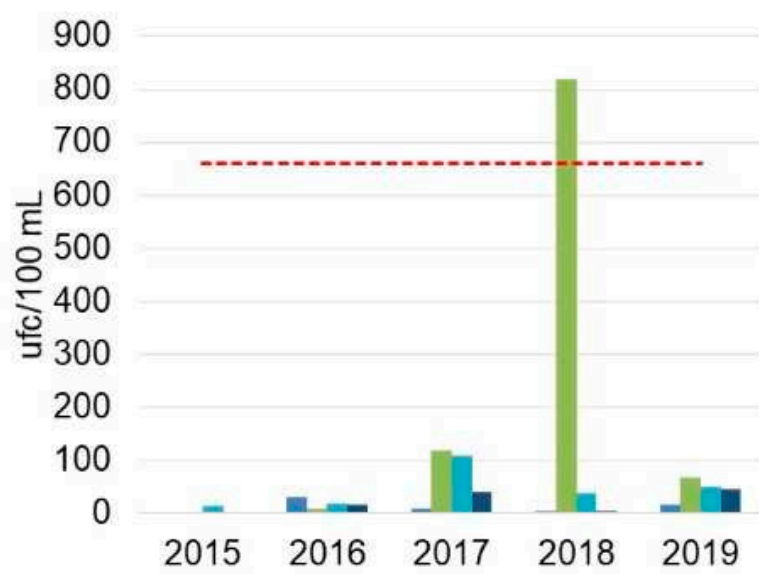

(d) Cavadinho - intestinal Enterococci 600

$$
500
$$

$\vec{E}^{400}$
$\stackrel{8}{\circ} 300$
$\stackrel{\frac{C}{d}}{J} 200$

100

0 $\begin{array}{lllll}2015 & 2016 & 2017 & 2018 & 2019\end{array}$ (f) Navarra - intestinal Enterococci

Figure 4. Cont. 


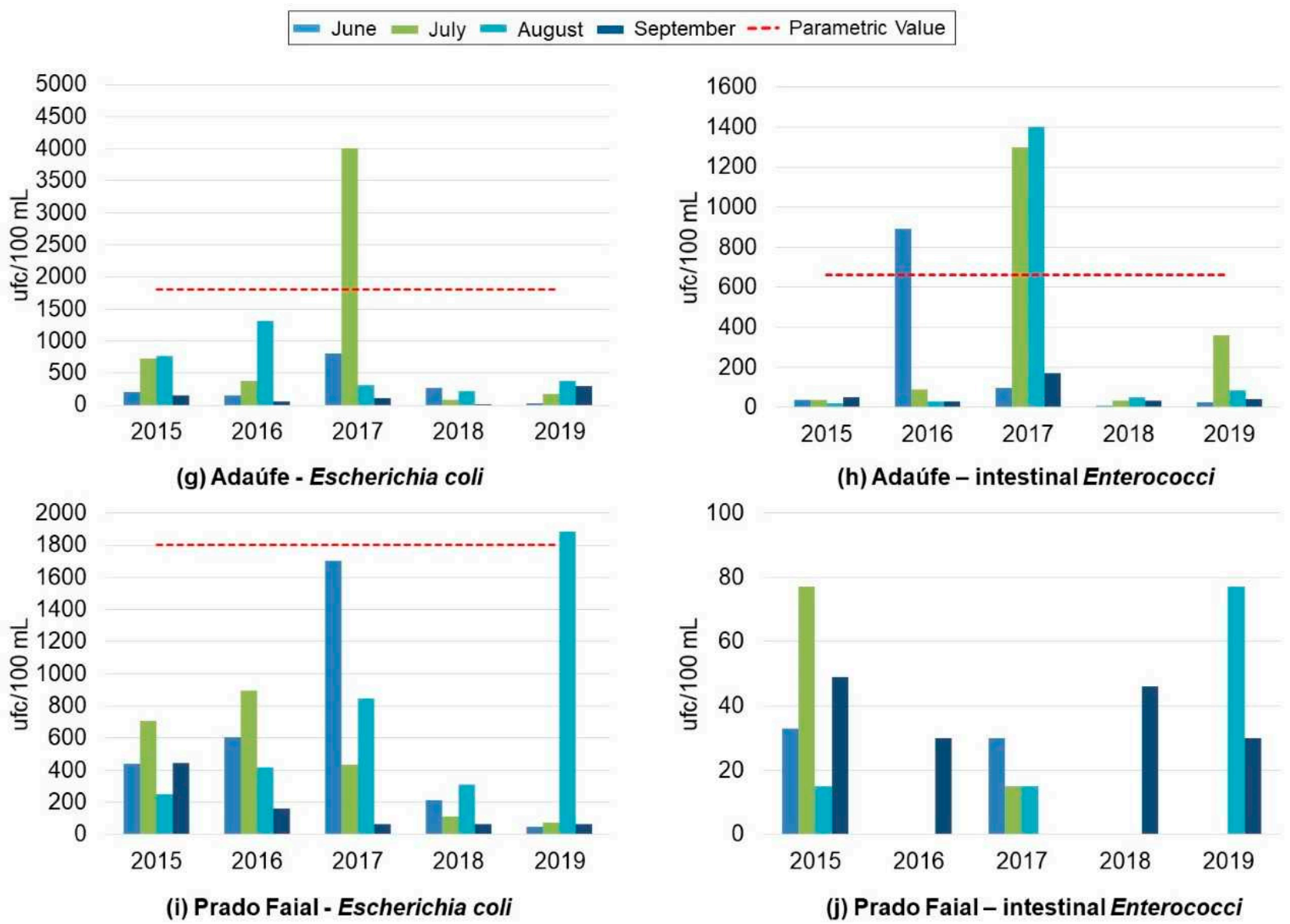

Figure 4. Temporal variation of maximum values for microbiological parameters from water river beaches.

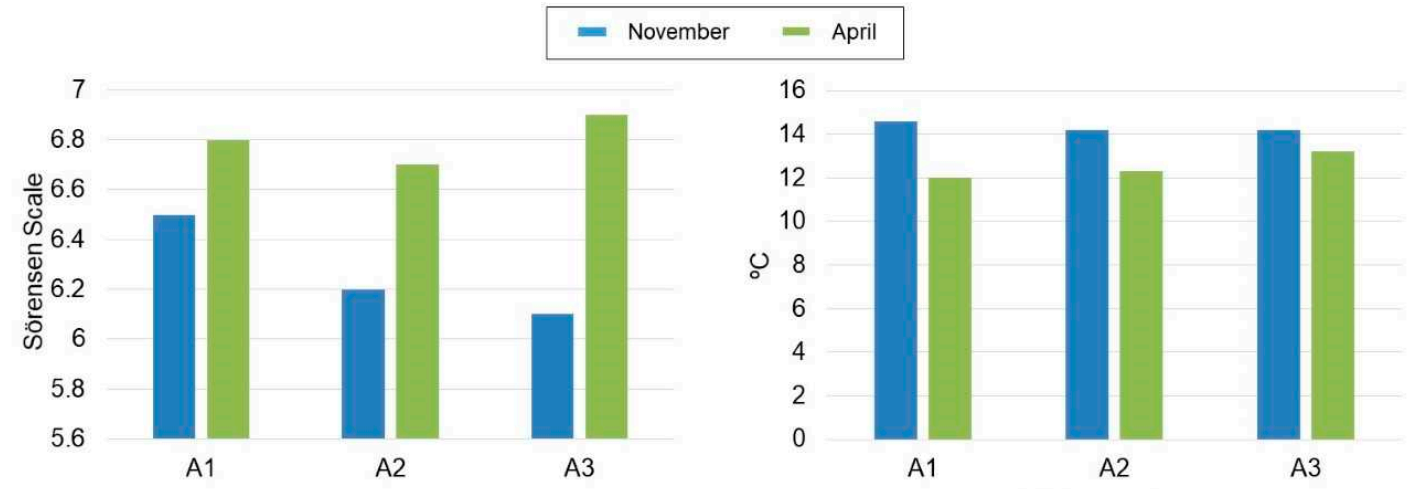

(a) $\mathrm{pH}$

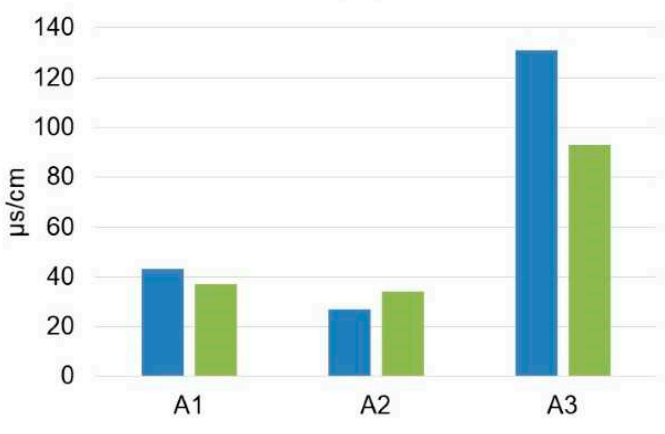

(c) Electrical Conductivity

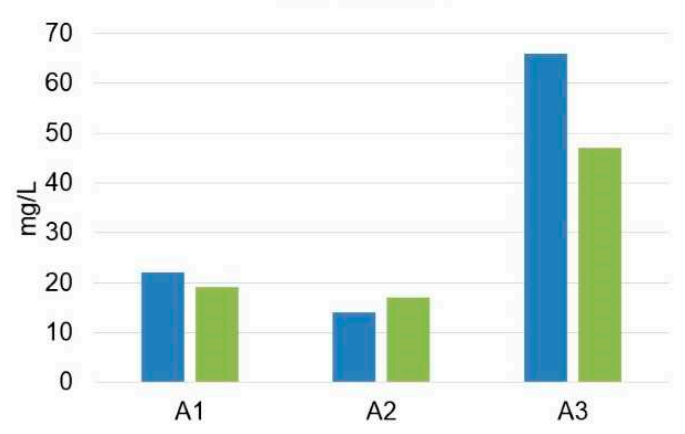

(d) Total Dissolved Solids

Figure 5. Water seasonal variation from the Cávado River. Water samples reference the same as in Figure 3. 


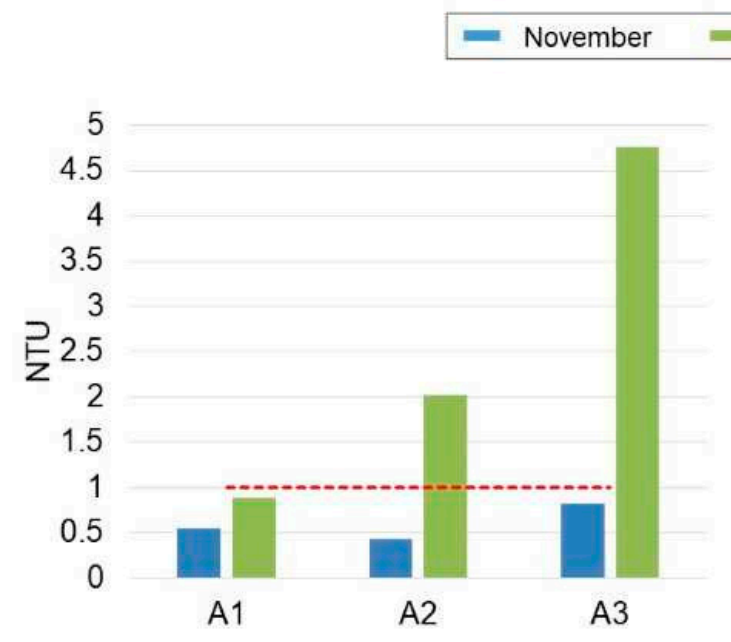

(a) Turbidity

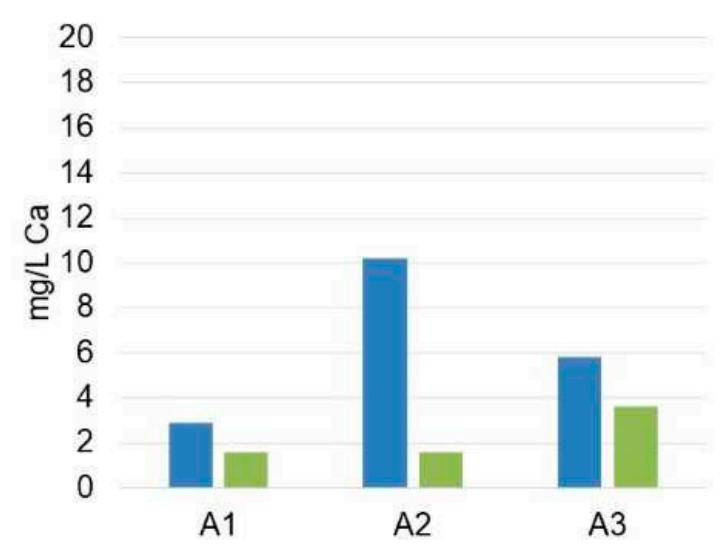

(c) $\mathrm{Ca}$

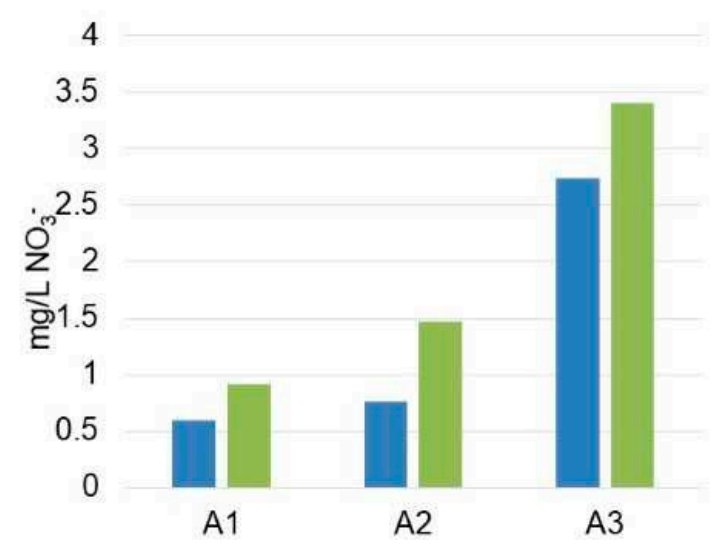

(e) $\mathrm{NO}_{3}{ }^{-}$

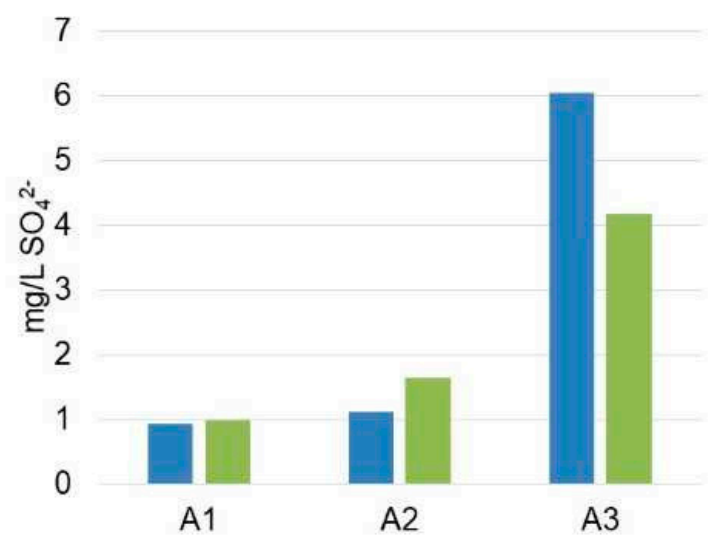

(b) $\mathrm{SO}_{4}{ }^{2 \cdot}$

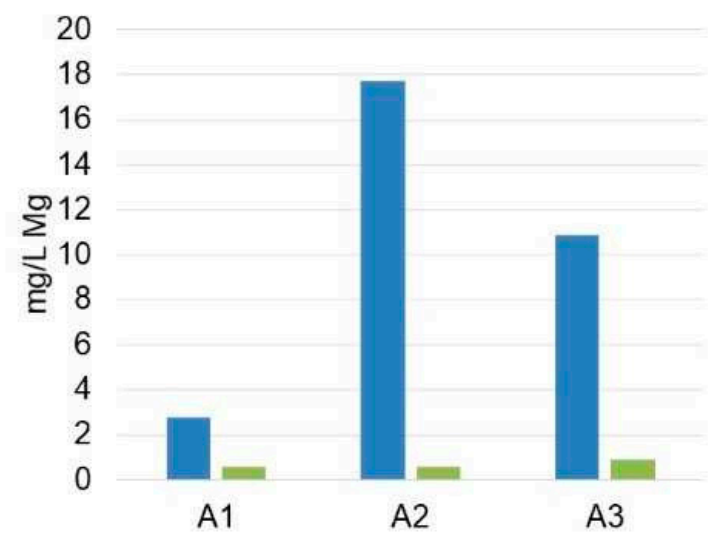

(d) Mg

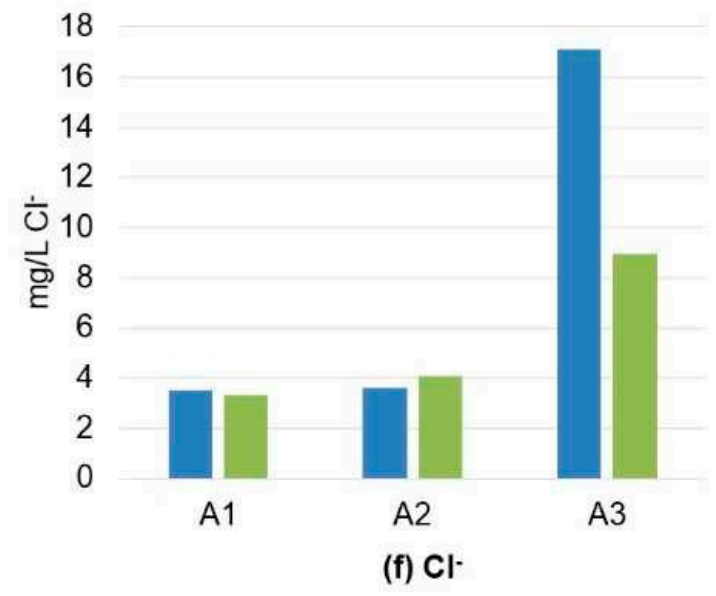

Figure 6. Physicochemical parameters of the water from the Cávado River. Water samples reference the same as in Figure 3.

The water $\mathrm{pH}$ and temperature values did not show a regular spatial and temporal variation. The water for the sampling point $\mathrm{A} 3$ presents the highest $\mathrm{EC}$ and total dissolved solids values in both campaigns (Figure 5). The water Eh ranges between $126 \mathrm{mV}$ to $185 \mathrm{mV}$ without a significant variation. 
The sampling point A2 shows the highest value of alkalinity (33 mg/L), Ca (10.2 mg/L), $\mathrm{Mg}(17.7 \mathrm{mg} / \mathrm{L}), \mathrm{Br}(0.121 \mathrm{mg} / \mathrm{L}), \mathrm{F}^{-}(0.082 \mathrm{mg} / \mathrm{L})$ and $\mathrm{Cd}(19.1 \mu \mathrm{g} / \mathrm{L})$ (Figure 6 and Table 1). Otherwise, the water from A3 sampling point contains higher Al $(103 \mu \mathrm{g} / \mathrm{L})$, $\mathrm{NH}_{4}{ }^{+}(2.06 \mathrm{mg} / \mathrm{L}), \mathrm{Fe}(126 \mu \mathrm{g} / \mathrm{L}), \mathrm{PO}_{4}{ }^{3-}(0.356 \mathrm{mg} / \mathrm{L}), \mathrm{Mn}(26 \mu \mathrm{g} / \mathrm{L}), \mathrm{K}(3 \mathrm{mg} / \mathrm{L}), \mathrm{Na}$ (14 mg/L), $\mathrm{Cr}(0.45 \mu \mathrm{g} / \mathrm{L}), \mathrm{Li}(1.1 \mu \mathrm{g} / \mathrm{L}), \mathrm{NO}_{2}{ }^{-}(2.217 \mathrm{mg} / \mathrm{L})$, bicarbonates $(23 \mathrm{mg} / \mathrm{L})$, and turbidity (4.76 NTU) values than the other water sampling points (Figure 6 and Table 1). The water from sampling points $\mathrm{A} 2$ and $\mathrm{A} 3$ are contaminated in $\mathrm{Cd}$ and turbidity, and in $\mathrm{NH}_{4}{ }^{+}, \mathrm{NO}_{2}{ }^{-}$, and turbidity, respectively.

\section{Discussion}

The water from river beaches located upstream of the town of Braga-Alqueirão, Cavadinho, Navarra, and Adaúfe-shows lower microbiological parameter values, indicating that the water has a "good quality". However, the maximum water microbiological contents are higher than the corresponding parametric value in the water of river beach from Adaúfe (June 2016, July and August 2017), and in the water of river beach from Cavadinho (July 2018). The water contamination could be related to effluent discharges or to agricultural activities located around the area, which caused faecal contamination.

The occurrence of extreme rainfalls could also be a cause of contamination because of runoff transport microorganisms [15,21,31]. The water from the river beach of Prado Faial registered the highest Escherichia coli values in the last five years, which could be explained by the proximity of Homem River, a tributary to Cávado River, and associated agricultural areas and non-regular water discharges [31]. The beach of Prado Faial is also influenced by the wastewater treatment plants of Braga (Figure 3).

However, during 2018, a water quality improvement was registered, and, consequently, the river beach from Prado Faial obtained the classification of "good quality" [25]. In August 2019, there is a punctual increase in Escherichia coli content. The water from river beaches located upstream of the Prado Faial river beach had a better water quality.

The values of physicochemical parameters were not enough to make conclusions about temporal water quality in the Cávado River. However, the results showed that there are some places in the river with different values. The water from sampling point A1 has an excellent quality, justified by the reduced urban and industrial associated pressure. The water from sampling points A2 and A3 are contaminated relatively to some parameters. The water from sampling point A2 is contaminated in Cd and has a high turbidity value, which could be associated with the occurrence of accidental discharges, representing local contamination episodes. This water sampling point also registers the highest calcium, magnesium, fluoride, bromide, and alkalinity values. However, generally, the results of the chemical analysis on water sampling from point A3 are higher than the results on water from sampling point A2.

Some water parameter values show a progressive increase from water sampling point A1 to A3. Water chromium, phosphate, and ammonium contents were only detected in water sampling point A3 and the values of turbidity, ammonium, and nitrites contents are higher than the corresponding legislated parametric values. The occurrence of industry is higher in Braga and Barcelos municipalities. One of the two industrial parks in Braga (Industrial park of Padim da Graça) is near the water sampling point A3 [23,31]. The increase in the results of the chemical analysis on water is associated with the presence of industrial and agricultural activities in the area $[23,31]$ and/or the occurrence of possible accidental discharges.

\section{Conclusions}

The main conclusions relative to the water quality management of the river beaches from the Cávado River watershed considers that:

1. Generally, the river beach water quality has been significantly improved over the last five years, mainly justified by the deactivation of Amares Wastewater Treat- 
ment Plants, considered as one of the main sources of contamination in the Cávado River [31].

2. The river beach from Alqueirão, Cavadinho, Navarra and Adaúfe obtained the classification of "good and excellent" water quality, in 2019.

3. Water quality of river beaches is influenced by land use and water management within the watershed.

4. The water quality of the Cávado River shows a gradual deterioration of the flow river from upstream to downstream mainly due to population agglomerations, especially in Braga municipality as well as industrial and agricultural activities.

5. The improvement of water river quality will allow the potential to recognize other inland beaches and a local/regional increase in tourism development. For mitigation, the following methods are proposed.

- Implementation of water quality monitoring of River Cávado and its main affluents, using physicochemical and microbiological parameters in the regular and continuous period.

- Recognition of possible contamination sources nearly from river beaches of River Cávado.

- Development and application of predictive models to provide faster information about microbiological contamination in inland beaches [18,32].

- Development of awareness-raising programs for the population to promote sensibilization about water sustainability, and for the local agents to promote the use of better practices in the management of Wastewater Treatment Plants infrastructures and the minimization of the use of pesticides and herbicides in agriculture.

Author Contributions: All authors have contributed extensively to the work presented in the paper. Conceptualization, M.A. and A.C. Methodology, M.A., M.O. and A.C. Data curation, M.A. and M.O. Writing-original draft preparation, M.A., M.O. and A.C. Writing-review and editing, M.A., M.O. and A.C. All authors have read and agreed to the published version of the manuscript.

Funding: This research was funded by Braga Municipality and FCT—Fundação para a Ciência e a Tecnologia, I.P., grants numbers UIDB/04683/2020, UIDP/04683/2020.

Institutional Review Board Statement: Not applicable.

Informed Consent Statement: Not applicable.

Data Availability Statement: Not applicable.

Acknowledgments: The author thank Braga Municipality and FCT-Fundação para a Ciência e a Tecnologia, I.P., through the projects reference UIDB/04683/2020, UIDP/04683/2020. The authors acknowledge the anonymous reviewers for the constructive comments that helped to improve the quality of the manuscript.

Conflicts of Interest: The authors declare no conflict of interest.

\section{References}

1. European Union. Directive 2006/7/EC of the European Parliament and of the Council of 15 February 2006 concerning the management of bathing water quality and repealing Directive 76/160/EEC. Off. J. Eur. Union 2006, 64, 37-51.

2. Goldstein, S. Caracterização Ambiental de Praias Fluviais de Portugal Continental. Master's Thesis, University of Lisboa, Lisboa, Portugal, 2011.

3. SNIRH. Dados Sintetizados—Águas balneares. Available online: https://snirh.apambiente.pt/index.php?idMain=1\&idItem=2.1 (accessed on 16 December 2018).

4. Moreira, C.O. E Santos, N.P.D. Turismo Fluvial em Portugal Continental: Oferta e Potencialidades; Water Territories; CEGOT: Coimbra, Portugal, 2016; pp. 255-271. Available online: hdl.handle.net/10316/47544 (accessed on 27 March 2021).

5. APA. Diretiva das Águas Balneares. Available online: https://www.apambiente.pt/index.php? ref=16\&subref=7\&sub2ref=818\& sub3ref $=1290$ (accessed on 30 June 2019).

6. Ouattara, N.K.; Garcia-Armisen, T.; Anzil, A.; Brion, N.; Servais, P. Impact of Wastewater Release on the Faecal Contamination of a Small Urban River: The Zenne River in Brussels (Belgium). Water Air Soil Pol. 2014, 225, 2043. [CrossRef] 
7. Stocker, M.D.; Smith, J.E.; Hernandez, C.; Macarisin, D.; Pachepsky, Y. Seasonality of E. coli and Enterococci Concentrations in Creek Water, Sediment, and Periphyton. Water Air Soil Pol. 2019, 230, 223. [CrossRef]

8. European Environmental Agency. European Water Policies and Human Health-Combining Reported Environmental Information; Publications Office of the European Union: Luxembourg, 2016; pp. 23-24. [CrossRef]

9. European Environmental Agency. European Bathing Water Quality in 2017; APAmbiente SNIRH Dados de Base. Publications Office of the European Union: Luxembourg, 2018; p. 8. Available online: https:/ / snirh.apambiente.pt/index.php?idMain=2\&idItem=1 (accessed on 6 October 2020).

10. Kirschner, A.K.T.; Reischer, G.H.; Jakwerth, S.; Savio, D.; Ixenmaier, S.; Toth, E.; Sommer, R.; Mach, R.L.; Linke, R.; Eiler, A. Multiparametric monitoring of microbial faecal pollution reveals the dominance of human contamination along the whole Danube River. Water Res. 2017, 124, 543-555. [CrossRef] [PubMed]

11. Kay, D.; Crowther, J.; Stapleton, C.M.; Wyer, M.D.; Fewtrell, L.; Edwards, A.; Francis, C.A.; McDonald, A.T.; Watkins, J.; Wilkinson, J. Faecal indicator organism concentrations in sewage and treated effluents. Water Res. 2008, 42, 442-454. [CrossRef] [PubMed]

12. Servais, P.; Garcia-Armisen, T.; George, I.; Billen, G. Fecal bacteria in the rivers of the Seine drainage network (France): Sources, fate and modelling. Sci. Total Environ. 2007, 375, 152-167. [CrossRef] [PubMed]

13. Owa, F.W. Water pollution: Sources, effects, control and management. Medit. J. Soc. Sci. 2003, 4, 65-68. [CrossRef]

14. Quilliam, R.S.; Taylor, J.; Oliver, D.M. The disparity between regulatory measurements of E. coli in public bathing waters and the public expectation of bathing water quality. J. Environ. Manag. 2019, 232, 868-874. [CrossRef] [PubMed]

15. Kistemann, T.; Schmidt, A.; Flemming, H.C. Post-industrial river water quality-Fit for bathing again? Int. J. Hyg. Environ. Health 2016, 219, 629-642. [CrossRef] [PubMed]

16. World Health Organization. Guidelines for Safe Recreational Water Environments Volume 1: Coastal and Fresh Waters; World Health Organization: Geneva, Switzerland, 2004; Chapter 4; p. 53. ISBN 92-4-154580 1.

17. Williams, A.P.; Quilliam, R.S.; Thorn, C.E.; Cooper, D.; Reynolds, B.; Jones, D.L. Influence of Land Use and Nutrient Flux on Metabolic Activity of E. coli O157 in River Water. Water Air Soil Pol. 2012, 223, 3077-3083. [CrossRef]

18. Dada, A.C.; Hamilton, D.P. Predictive Models for Determination of E. coli Concentrations at Inland Recreational Beaches. Water Air Soil Pol. 2016, 227, 347. [CrossRef]

19. Mika, K.B.; Ginsburg, D.W.; Lee, C.M.; Thulsiraj, V.; Jay, J.A. Fecal Indicator Bacteria Levels Do Not Correspond with Incidence of Human-Associated HF183 Bacteroides 16S rRNA Genetic Marker in Two Urban Southern California Watersheds. Water Air Soil Pol. 2014, 225, 1960. [CrossRef]

20. Ministério do Ambiente, do Ordenamento do Território e do Desenvolvimento Regional. Decreto-Lei n. ${ }^{\circ}$ 135/2009, $n^{\circ}$ 107; Diário de República: Lisboa, Portugal, 2009; pp. 3460-3468.

21. Ministério do Ambiente, do Ordenamento do Território e do Desenvolvimento Regional. Decreto-Lei n. $.^{\circ} 113 / 2012, n^{\circ} 100$; Diário da República: Lisboa, Portugal, 2012; pp. 2715-2726.

22. CIM Cávado. Rede Praias Fluviais do Cávado. Available online: https://www.cimcavado.pt/2017/08/10/rede-de-praiasfluviais-do-cavado/ (accessed on 16 June 2019).

23. Agência Portuguesa do Ambiente. Parte 2-Caracterização e Diagnóstico. Plano de Gestão da Região Hidrográfica do Cávado, Ave e Leça (RH2); APA: Lisboa, Portugal, 2016; pp. 1-4.

24. EEA \& Copernicus Land Service. Corine Land Cover. 2018. Available online: https://land.copernicus.eu/pan-european/corineland-cover/clc2018 (accessed on 27 May 2019).

25. Luís, J.C.M. Hidroconflitos na Bacia Hidrográfica do Rio Cávado-Uma Análise Geográfica a Partir do Contributo do Serviço de Proteção da Natureza e do Ambiente. Master's Thesis, University of Minho, Braga, Portugal, 2003.

26. Brito, A.G.; Pinho, J.L.; Costa, S. Estudo de Valorização e Desenvolvimento Estratégico Dos Rios Cávado e Homem: Conhecer e Preservar para Usufruir: Relatório Final; Associação de Municípios do Vale do Cávado: Braga, Portugal, 2008; p. 15. ISBN 978-989-95862-0-8.

27. APA. ARH Norte Águas Balneares Interiores. Available online: https:/ / www.apambiente.pt/index.php?ref=19\&subref=906\& sub2ref=916\#Interiores (accessed on 22 March 2020).

28. American Public Health Association. Standard Methods for the Examination of Water and Wastewater, 18th ed.; American Public Health Association: Washington, DC, USA, 1992.

29. Ministério do Ambiente. Decreto-Lei n. ${ }^{\circ}$ 236/1998, $n^{\circ}$ 176; Diário da República: Lisboa, Portugal, 1998 ; pp. 3676-3722.

30. Ministério do Ambiente, do Ordenamento do Território e do Desenvolvimento Regional. Decreto-Lei n..$^{\circ}$ 306/2017, $n^{\circ} 164$; Diário da República: Lisboa, Portugal, 2017; pp. 5747-5765.

31. Oliveira, M.A.V. Avaliação da Qualidade da Água das Praias Fluviais na Bacia do Rio Cávado—Propostas de Melhoria Ambiental. Master's Thesis, University of Minho, Braga, Portugal, 2019.

32. Oliver, D.M.; Porter, K.D.H.; Pachepsky, Y.A.; Muirhead, R.W.; Reaneyd, S.M.; Coffey, R.; Kay, D.; Milledge, D.G.; Hong, E.; Anthony, S.G. Predicting microbial water quality with models: Over-arching questions for managing risk in agricultural catchments. Sci. Total Environ. 2016, 544, 39-47. [CrossRef] [PubMed] 